\title{
Introduction: Recurrence, Transference, and Dmitry
}

If history were taught in the form of stories, it would never be forgotten.

— Rudyard Kipling

I n the spring of 1605, a young man purporting to be Dmitry, Ivan IV's sole surviving son, ascended Moscow's throne. Eleven months later, he was dead-the victim of a murderous conspiracy. A brutal, eight-year struggle for sovereignty erupted.

News of Dmitry's precipitous rise and fall spread rapidly across Russia and into western Europe, ${ }^{1}$ but his true identity and aspirations are disputed to this day. Was he indeed the last son of Russia's “Terrible” tsar, miraculously rescued from an assassination attempt in 1591? Or was he a pretender, as his detractors alleged? Did he rule the Russian lands wisely, or was he little more than an adventurer? Unfortunately, history offers few definitive answers: the evidence is limited and flawed. Yet the man who would be tsar has provided a perennial source of fascination-precisely because of the mystery that surrounds him. Dozens of dramas, novels, and monographs - written across centuries as well as national borders - have offered riveting accounts of Dmitry and his deeds, sparking as much as slaking the curiosity of successive generations of readers.

We might easily imagine that the enigma of Dmitry-his debatable origins, his uncertain allegiances, the conflicting passions he inspired among supporters and disparagers - would titillate sensation seekers. What is somewhat less expected, however, is the abiding attraction he has exercised over successive generations of Russian novelists and dramatists. Writer after writer adapted selected aspects of his story as narrative scaffoldings for their own fictional works, often drawing explicit attention to their acts of appropriation

1 For a list of plays written about Dmitry, see Erwin C. Brody, The Demetrius Legend and Its Literary Treatment in the Age of the Baroque (Rutherford, NJ: Fairleigh Dickinson University Press, 1972). See also his "Pushkin's 'Boris Godunov': The First Modern Russian Historical Drama," Modern Language Review 72 (1977): 858-59. 
by choosing the same familiar titles for their plays and novels (most frequently, Dmitry the Pretender). Why were so many belletrists drawn to Dmitry?

Writing the Time of Troubles identifies four successive waves of eighteenthand nineteenth-century Russian writers who coopted the equivocal person of Dmitry not just as a thrilling protagonist for historical plays and novels but also as a vehicle for addressing and contesting identity-Dmitry's own, to be sure, but also modern Russia's. In their works, politics - past and present-seeped into and mixed with fiction, compelling these playwrights and novelists to ask the following: was Dmitry (or Russia) unique, the product of providential exceptionalism? Or was he (and, by extension, Russia) a fabricated construct, an alloy of east and west? Was Dmitry (or Russia) true to Orthodoxy, or had he (and Russia) yielded to apostasy? Was the unhappy turn that Russian history made after Dmitry's downfall his fault or the boyars'? Put differently, could early seventeenth-century Russia's trauma be traced to a single "great man"? To a congeries of boyars? To "the people"? What were the implications of past trauma for the present? The dual focus of these questions - on the premodern Dmitry and on modern society-tied Russian writers' present ineluctably to their medieval past, revealing their intuition that vital aspects of Old Russia's legacy remained intact and relevant even after Peter the Great's reforms.

Of course, all human societies experience trauma at some point in their histories. The aspects that differentiate one society from another in this regard are the shape and scope of its trauma as well as the means that it adopts to come to terms with it. Russia underwent a crisis in the opening years of the seventeenth century that shook it to its core and that has never been fully overcome. ${ }^{2}$ Later writers would tie the period's conundrums to similar dilemmas in their own times, asking whether time-honored traditions were necessarily sacrosanct and whether true rulers must be born or could be chosen. It is characteristic of Russian culture that several generations of intellectuals repeatedly interrogated these issues through works of belles lettres. It is also characteristic that subsequent experiences of trauma were assimilated to the seventeenth century's ur-trauma: the earlier period's uncertainties remained both foundational and, to a great extent, unresolved. Imperial Russia's historical fiction about Dmitry fell into two main subtypes: static texts that

2 In Daniel Rowland's words, "The events of the Troubles, including the virtual disappearance of the God-established tsardom, violent social strife, and massive foreign intervention, were so traumatic that they forced writers to search deeply in their stock of received ideas for some sort of explanation" ("Did Muscovite Literary Ideology Place Limits on the Power of the Tsar [1540s-1660s]?” Russian Review 49 [1990]: 131). 
viewed modern realities as the preordained outcome of early modern crises and dynamic texts that celebrated the allure and possibility of change.

During Russia's imperial period, both belletrists and historians worked with the Dmitry material, each appropriating insights from the other. Members of both callings generally made one of two assumptions regarding the historical Dmitry: either his life had come to a tragic end in 1591, or it was providentially prolonged until 1606. Which assumption they supported was a function more of subjective preference than of facts: the known "facts" could not be made to privilege one answer over the other, since the seventeenth-century documents containing them were, more often than not, heavily infused with propaganda and replete with authorial bias.

While it will probably never be possible to render a "true" accounting of Dmitry's life, a stock version of it has coalesced over time. Its veracity can be debated, but its popularity cannot. Based in large part on documented events but also on polemical assertions and imaginative flourishes, the story begins with Ivan IV the Terrible's union with Maria Nagaya, his sixth or possibly seventh wife, and the birth of their son Dmitry. ${ }^{3}$ After Ivan's death in 1584, Fyodor, his oldest surviving son, ascended the throne. According to many contemporaries, the new tsar was weak in mind and body; as a result, he relied heavily on his brother-in-law, Boris Godunov, to manage day-to-day affairs. One of Godunov's first orders of business was to exile Fyodor's much younger halfbrother to the provincial town of Uglich, where he was said to have died of a knife wound in May 1591. Godunov reacted to Dmitry's presumed passing by dispatching an investigatory commission to Uglich. Based on the testimony of townsfolk, the commission concluded that the boy had fallen on his own knife during an epileptic seizure. Although rumors that the child had been murdered immediately began to circulate among certain Russians and resident foreigners, few at the time seem to have given protracted thought to his sadly foreshortened life.

In 1598 Tsar Fyodor died without surviving issue, and with him died the Moscow line of the Rurikid dynasty, which had presided over the Russian lands for more than six hundred years. After several weeks of frenzied machinations, a national assembly offered the crown to Boris Godunov. At first Godunov prospered, and his modest efforts toward modernization and rapprochement with the west met with approval. But in the opening years of the new century, famine and disease descended on Russia and undermined the good will the

3 There is disagreement as to whether one of Ivan's prior marriages was actually formalized. 
boyar tsar had earned through his earlier successes. ${ }^{4}$ As conditions worsened, Russians began to impugn Godunov for having seized a throne to which he had not been born. Reports proliferated suggesting that in 1591, in anticipation of the childless Fyodor's demise, Godunov had ordered Dmitry's death. He could do nothing to forestall these rumors. More alarming still, in 1603 a young man surfaced in Poland claiming to be Dmitry, miraculously preserved from death. Godunov insisted that the man in question was a defrocked monk named Grigory Otrepev, but his claims rang hollow, and Russians began to flock to Dmitry's banner.

With backing from Poland - which coveted Russia's lands - and Romewhich coveted its souls-Dmitry/Otrepev, subsequently known as the First False Dmitry, marched on Russia. Boris Godunov mounted a hard-fought defense against the pretender but succumbed to a stroke in April 1605. Many of Moscow's leading boyars, including its most capable general, Pyotr Basmanov, took the occasion of Godunov's death to betray Fyodor Godunov, Boris's son and successor. These acts of treachery secured Dmitry's victory. Once Moscow had been captured and subdued, Dmitry ordered Godunov's wife and son put to death, sparing only his daughter, Xenya, whom, according to his detractors, he reserved for his own pleasure.

His alleged depredations against the Godunov family notwithstanding, Dmitry was one of Russia's more progressive rulers. To a greater extent than Godunov, he fostered relations with the west, and he chose his wife, Marina Mniszek, from among the ranks of Poland's noblewomen. He sought to reform Russia's economy and government and planned to sponsor schools. Unfortunately, his projects enraged his detractors and served as one of the pretexts for Prince Vasily Shuisky's coup against him in 1606.

Vasily Shuisky became tsar after Dmitry. His authority was tenuous, however, and a host of new claimants to the throne, pretending to be variously attested and unattested scions of the ruling line of the House of Rurik, crept out of Russia's woodwork to plague and undermine him. In 1610 Shuisky was deposed and forced to take monastic orders. During the course of these events, King Sigismund of Poland conspired to put his son, Władysław, on the Russian throne. It was not until the autumn of 1612 that Russian patriots managed to drive the Poles from Moscow under the joint leadership of a merchant, Kuzma

4 For a succinct summary of the epidemics that overtook Russia in the opening years of the seventeenth century, see John T. Alexander, Bubonic Plague in Early Modern Russia: Public Health and Urban Disaster (Oxford: Oxford University Press, 2003), 17. 
Minin, and a nobleman, Prince Dmitry Pozharsky. In early 1613 a national assembly "elected" the sixteen-year-old Mikhail Romanov tsar, and Russia began its long process of healing.

The period between Fyodor's death in 1598 and Mikhail's election in 1613 has come to be known as the Smuta, or Time of Troubles. ${ }^{5}$ During these years, Russians suffered untold privations, and hunger and disease stalked the land. Robber bands and foreign invaders raped and pillaged. Pretenders multiplied vertiginously, securing the allegiance of various boyar factions and contending among themselves for primacy. Lines of political authority vanished, as did the hope that a "true" tsar might be found.

The Russia of the Troubles was a premodern society. Its inhabitants, who were largely illiterate and too thinly settled across eastern Europe's vast expanses to have reliable access to news, looked to the Orthodox Church to inform and guide them. Information came, as often as not, in the form of rumors. The Troubles, during which highly exaggerated stories of Godunov's murderous proclivities and Dmitry's intentions to convert Russia to Catholicism spread wildly, scarred the country and provoked a concerted reaction. In the face of terrible hunger and disease, Russians fought doggedly for the two institutions they held most dear-their sovereign dynasty and the Orthodox Church. Even today, their struggles continue to animate historiography and literature.

Russian literature is no stranger to recurrent characters and plotlines: novelists and playwrights have regularly enlisted the most varied and colorful episodes of Russian history as inspiration for their works. The protagonists and the events of the oprichnina, the Time of Troubles, the era of palace coups, the Napoleonic Wars, as well as a host of others have all provided inspiration. Western Europe has likewise contributed rich material: Russian adaptations and imitations of such classics as Romeo and Juliet, Hamlet, and Faust abound. In Writing the Time of Troubles, however, I examine a specifically Russian protagonist within the context of Russian literature. In doing so, I analyze representations of Dmitry in terms of the culture that produced and reproduced him. Moreover - unlike literary rewritings of Romeo, Juliet, or FaustDmitry is both a literary construct and a "real," "historical" figure; the dramatists and novelists who have immortalized him have frequently, if not always,

5 In dating the onset of the Time of Troubles to 1598, I follow Chester S. L. Dunning, Russia's First Civil War: The Time of Troubles and the Founding of the Romanov Dynasty (University Park: Pennsylvania State University Press, 2001), 1. 
appropriated material and interpretations from the histories written by their contemporaries. Therefore, while writing about literature, I will from time to time also make reference to history.

Why focus on Dmitry rather than his predecessor, Boris Godunov, or his successor, Vasily Shuisky-both of whom have also figured prominently in Russian literature? Why not the even more famous Ivan the Terrible or Peter the Great? ${ }^{6}$ In part, the answer lies in the seventeenth-century protohistorical material that dramatists and novelists drew on in portraying Dmitry. In the eyes of seventeenth-, eighteenth-, and some nineteenth-century men of letters, the material was bounded and closed: Dmitry was a pretender; Vasily Shuisky made a precipitous end of him; a new royal dynasty arose to vitiate and erase his reign. His story was told variously as a cautionary tale, a means of effacing dangerous new ideas, and/or a foretokening of the Romanovs, but it always ended in the same way-with Dmitry consigned to the abyss. Yet the material could also be read quite differently, as radically open-ended. Some of the nineteenth century's most gifted writers came to wonder whether the man who ruled as Dmitry might not actually have been who he claimed to be, oreven if he was not-whether he might not have offered Russia a different, freer future. Several of the century's Dmitry fictions explore his plans for Russia. What might have happened if his career had not been cut short? Might life have been more vibrant, more just? In these readings, Dmitry was a tabula rasa: he arose from nowhere, implausibly and with no credible witnesses to vouch for him. As a newcomer and a figure of mystery, he offered a novel vision of what Russians might do and who they might become. Thus, for a number of nineteenthcentury belletrists, Dmitry was a man of infinite possibilities: his outer life was

6 Indeed, excellent studies of these figures already exist. N. V. Riasanovsky has applied the tools of intellectual history to stories about Peter in order to document the evolution of his image over time (The Image of Peter the Great in Russian History and Thought [New York: Oxford University Press, 1992]). Xenia Gasiorowska mined many of the same stories in order to synthesize a "composite image" (Xenia Gasiorowska, The Image of Peter the Great in Russian Fiction [Madison: University of Wisconsin Press, 1979]). Kevin M. F. Platt has read Peter the Great and Ivan the Terrible as "heroic figures and avatars of social identity" and uncovered the relations between Russian culture and politics as well as the ways in which Russians produced and used history (Terror and Greatness: Ivan and Peter as Russian Myths [Ithaca, NY: Cornell University Press, 2011]). Caryl Emerson examined literary, histori$\mathrm{cal}$, and musical instantiations of Boris Godunov's story and documented its rich potential for generic transposition (Boris Godunov: Transpositions of a Russian Theme [Bloomington: Indiana University Press, 1986]). 
poorly documented, his inner life hardly documented at all. These lacunae begged to be filled by fiction.

By contrast, the "real" biographies of other famous late medieval and early modern figures have always been, if hardly rich, then at least richer in historical detail. Their substance is better articulated and attested to. Boris Godunov, for example, occupied a known place within Russian society: his forebears were documented as was his alliance with the Russian royal family. His deeds spanned many years and were attested to in Russian chronicles and western European travelogues. From a literary perspective, his outer world offers less fertile soil for fictive intervention than Dmitry's; it is his inner world that fascinates. Nineteenth-century dramatists asked how Godunov understood his own aspirations and what it cost him to pursue them. Heady stuff indeed: Godunov's inner life makes for great psychological drama. But his outer life is less conducive to imaginative reworking and less susceptible to fictionalization, thereby narrowing the range of possibilities for belles lettres. The same could be said for the other great player in early seventeenth-century Russia's power games, Vasily Shuisky. Like Godunov, Shuisky captured writers' attention because of his ambition — he was a man who sought to rise above the station to which he had been born but who tumbled back after forfeiting his contemporaries' affections and loyalties.

Ivan the Terrible has also spawned his share of fiction. Unlike Godunov and Shuisky, his aspirations never outran his possibilities - very much to the contrary, in fact. He traumatized his subjects by sham-abdicating his throne, rechristening himself "Ivan of Moscow," and going through the motions of ceding sovereignty to Simeon Bekbulatovich, a descendant of Russia's erstwhile Mongol overlords. Why did he shock his people in this way? Why did he pretend to abandon his throne? Again, fiction is well suited to fill these lacunae. However, Ivan's outer world, like Boris Godunov's and Vasily Shuisky's, can be sketched in, even if only very approximately, on the basis of the facts of his "real" life. It is therefore only partially malleable. This hardly disqualifies him as a subject for fiction, but it does constrain an author's possibilities.

Considerably more is known about Peter the Great, who, like Ivan, briefly assumed a mock-humble name, "Peter Mikhailov," and abandoned his capital. While the meaning he ascribed to his actions remains an enigma, ripe for literary exploration, his outer world is comparatively well documented, lending itself as much to historical as to literary treatment. Dmitry, by contrast, has provided Russia's purveyors of fiction with broad imaginative scope. He represents the ultimate unknown and unknowable. Although a transformative 
thinker like Ivan IV, Boris Godunov, and Peter the Great, he nevertheless remains a man of obscure and contested origins, which has allowed imaginative authors to treat him both as tortured introvert and as swashbuckling extrovert. $\mathrm{He}$ is equally at home in tragedy and adventure fiction.

A second consideration in choosing to study Dmitry fictions is their protagonist's liminality. Dmitry intervened in Russian history after the Rurikids but before the Romanovs, at an in-between time in the country's dynastic fortunes. Subsequent commentators have disagreed as to whether he was a tyrant, a man of the people, or something between. Many have noted that he was crowned but perhaps not royal, Russian but beholden to Poland. Dmitry himself claimed to be an Orthodox believer, but his detractors derided him as a creature of the pope. Even his affairs of the heart are difficult to disentangle: was he a romantic lover, a cynical rapist, or a bit of both? As a historical actor, Dmitry simultaneously created and mediated oppositions, an aspect of his life that was carried over into representations of him as a fictional protagonist. ${ }^{7}$

Bjørn Thomassen has defined liminality as "moments or periods of transition during which the normal limits to thought, self-understanding and behavior are relaxed, opening the way to novelty and imagination, construction and destruction," a formulation that captures both the concrete shocks experienced by Russians living through the Time of Troubles and the more abstract notion of mediation embodied by the period. Hein Viljoen and Chris N. van der Merwe view such moments as ones in which an individual or a community loses its "plot": "working through a trauma involves rewriting the plot, incorporating the disaster in some way," in order to make its story intelligible and bearable. 9 They further note that "in a divided society different stories

7 Images in early Russian literature of Dmitry representing one pole or the other of a binary opposition are unsurprising. As Iu. M. Lotman and B. A. Uspenskii have written, "The basic cultural values (ideological, political, and religious) of medieval Russia were distributed in a bipolar field and divided by a sharp boundary without an axiologically neutral sphere" ("Binary Models in the Dynamics of Russian Culture [to the End of the Eighteenth Century]," in The Semiotics of Russian Cultural History, ed. Alexander D. Nakhimovsky and Alice Stone Nakhimovsky [Ithaca, NY: Cornell University Press, 1985], 31). The authors of late medieval tales and stories used Dmitry for their own sharply ideological purposes, creating a villain against whom they aimed their polemics.

8 Bjørn Thomassen, Liminality and the Modern: Living through the In-Between (Farnham: Ashgate, 2014), 1. Thomassen applies liminality to social and political theory rather than literature, but his insights have cross-disciplinary implications.

9 Hein Viljoen and Chris N. van der Merwe, "Introduction: A Poetics of Liminality and Hybridity," in Beyond the Threshold: Explorations of Liminality in Literature, ed. Chris N. van der Merwe and Hein Viljoen (New York: Peter Lang, 2007), 1. 
about the same events are told." ${ }^{10}$ Dmitry's early modern detractors denigrated him as the quintessential representative of novelty and destruction, the potentially negative term in a liminal equation; but a number of nineteenth-century writers recognized his positive capacity for imagination and construction. This recognition opened the way for belles lettres not only to document Dmitry's deeds but also to uncover their potential relevance for subsequent moments in Russian history. Dmitry fiction simultaneously mirrored the events that engendered it and created a foundation for new events; it offered a "reflection and enactment of boundaries in ... literary texts" 11 and served as "starting idea[s] to beget more crossing points." 12

The relationship between Russian history and fiction is hardly a new topic, and a number of important studies investigating it have appeared in the last several decades. Dan Ungurianu, for example, has authored an extensive survey and analysis of Russian historical novels of the imperial period. ${ }^{13}$ Andrew Baruch Wachtel has taken an intergeneric approach, comparing pairs of texts written by a single author, one historiographical, the other literary. $\mathrm{He}$ concludes that the authors he studies evidence "an implicit recognition that historical truth cannot be achieved through any one perspective" but rather "emerges from the uneasy coexistence of multiple ways of seeing and narrating the past." 14 Caryl Emerson's analysis of generic transpositions of Boris Godunov documents how "stories cohere as recognizable wholes in the process of a radical shift" across genre and medium. ${ }^{15}$ Focusing on revolutionary moments in Russian history, Kevin M. F. Platt asks, "What special possibilities for literary creation arise in ... periods of rapid transition from one set of social institutions to another, from one world to another?"16

My focus in Writing the Time of Troubles is neither as broad as Ungurianu's nor as compact as Platt's, since the cultural periods I examine are not bound to each other by a particular dominant like revolution. Unlike Emerson

10 Ibid., 2.

11 Ibid., 3.

12 Subha Mukherji, "Introduction: Thinking on the Threshold," in Thinking on Thresholds: The Poetics of Transitive Spaces, ed. Subha Mukherji (London: Anthem, 2011), xviii.

13 Dan Ungurianu, Plotting History: The Russian Historical Novel in the Imperial Age (Madison: University of Wisconsin Press, 2007).

14 Andrew Baruch Wachtel, An Obsession with History: Russian Writers Confront the Past (Stanford, CA: Stanford University Press, 1994), 12.

15 Emerson, Boris Godunov, 3.

16 Kevin M. F. Platt, History in a Grotesque Key: Russian Literature and the Idea of Revolution (Stanford, CA: Stanford University Press, 1997), 3. 
and Wachtel, I restrict myself to literary genres. The fictional Dmitry texts I examine date to multiple time periods but document only one. It is a notable peculiarity that they occur in clusters: the first cluster arose in the late eighteenth century; the second in the 1820s and 1830s; the third in 1866; and the fourth at the fin-de-siècle. This book seeks to illuminate two sets of circumstances: the general one of rewriting the Dmitry story, which I refer to as recurrence; and the particular one of each individual text's interactions with other fictional and nonfictional discourses of its day, which I refer to as transference. ${ }^{17}$

As a vertical, diachronic phenomenon, recurrence entails identifying the source materials for historical fiction and tracing how writers' knowledge of these materials changes over time. More important, it also entails tracing the evolution of the fictions themselves, for although they are often closely related to historiography, historical fictions constitute their own discrete mode of discourse and must be evaluated according to their own criteria. This is particularly challenging given that Russians have been less willing than many peoples to draw a sharp line between historiography and imaginative literature. As we shall see, Nikolay Karamzin, early nineteenth-century Russia's most celebrated historian, began his career in literature. Although he utilized impressive numbers of original source materials in his History of the Russian State, he also embroidered creatively on them, occasionally turning history into the facsimile of a psychological thriller. Alexander Pushkin, the progenitor of modern Russian literature, served as the empire's official historian; conversely, Mikhail Pogodin, best known as a historian, wrote fiction. None of these cases was unusual: Russian poet-historians have flourished throughout the centuries. As Aleksandr B. Kamenskii has argued, Russians, to a much greater extent than westerners, have believed that their future is constrained by their past: "The Russian, finding himself or herself at another crossroads in history . . pauses, ponders, and involuntarily glances back at the road already traveled, seeking in it the answer to the question of which road to take." 18 Thus, retelling the events of the Time of Troubles has been only one phase - albeit a highly significant one-in the larger, high-stakes project of fashioning an acceptable future from the past. Nothing less than the fate of Russia has depended on it.

Evaluating the foundational material for Dmitry fictions involves dividing premodern legends and stories into two distinct bodies: one concerning

17 I do not, of course, use "transference" in the psychoanalytic sense of unconsciously redirecting emotions from one person to another.

18 Aleksandr B. Kamenskii, The Russian Empire in the Eighteenth Century: Searching for a Place in the World, trans. and ed. David Griffiths (Armonk, NY: M. E. Sharpe, 1997), 5. 
Dmitry the child and one treating Dmitry the man. Unfortunately, the explanatory power of both types of sources is equivocal. The most apposite surviving official document dedicated to the child is the Investigatory Report on the Death of Tsarevich Dmitry Ivanovich of 1591 (Sledstvennoe delo o ubienii tsarevicha Dimitriia Ioannovicha 1591 goda), which is said to have been commissioned by Boris Godunov. The Report unquestionably reflects the biases of both its sponsor and its authors and is, accordingly, less than fully credible as a historical source. Moreover, the boy whose death prompted the investigation emerges as a pale and formless cypher, leaving a hole in the center of the narrative. The Report paints many vivid pictures - of grieving widows, bereaved mothers, nervous stablemen, and angry drunkards - but these highly interesting secondary characters displace Dmitry and dilute the Report's biographical merits. Other bits and pieces of Dmitry's childhood can be gleaned from oral legends and travelers' accounts, but like the Report, these sources generally focus on the aftershocks from his death rather than on his life. The earliest extant sources construct Dmitry as a function of his genealogy and social affiliations rather than as a person. A clearer picture of the living, breathing man emerges from the extensive body of seventeenth-century texts that cast Dmitry as an imposter. ${ }^{19}$ Nonetheless, while supplying the types of detail so saliently missing from the earlier stories, these sources deny the child's familial and social connections to the adult Dmitry; they detach him from his natal identity.

Thus, the Dmitry of late medieval and early modern sources survives as textually incomplete: he is either solely notional—a disembodied placeholder for dynastic aspirations - or solely actualized - a deracinated representative of action and adventure. The potential for and/or desirability of synthesizing these two sides of Dmitry's life seems to have eluded seventeenth-century Russian writers. Subsequent belletrists and historians who dealt with both bodies of source texts ultimately had to decide whether to link them and create an integrated human being or keep them separate and leave a biographical gap. In this sense, they faced the choice either of reading the disparate texts as different stages of the same story or of recognizing them as discrete entities. The stakes for historians were nothing less than ascertaining the "truth": they set out to marshal the facts conducing to Dmitry's rise and fall and, from them, to infer the political, economic, and social forces at work in early modern Russia. For belletrists, however, premodern truths were often less important than modern ones. They asked what the legends and tales about Dmitry revealed

19 Most of these texts have been printed in SGGD. 
about human nature-his own, his contemporaries', and their descendants'. Was his story temporally bounded, or was it exemplary of Russian cultural universals? If the latter, then were these universals nuanced, manifesting themselves differently at different times? The frequency with which belletrists posed such questions in the past has prompted me now to ask another: how can we explain the persistent rewriting of Dmitry's much-contested story?

Scholars in the field of trauma studies have recently addressed themselves to diverse instances in which literature has functioned to contextualize and process anguish and suffering. As Michelle Balaev has argued, the trauma in question may be experienced by either an individual or a group; the response to it may be unmediated or intergenerational. ${ }^{20}$ Alan Gibbs adds that trauma processing may aid either the perpetrator or the victim. ${ }^{21}$ As noted earlier, Viljoen and van der Merwe view trauma as a force that shatters life's coherence and gives rise to liminality. ${ }^{22}$ Thus, literature's response to trauma has been enlisted in a variety of causes. As a means of theorizing the writing of national cataclysm, trauma studies offer a fruitful avenue for exploring the recurrence of the Dmitry plot in Russian literature. It is tempting to identify Dmitry with Joseph Campbell's "hero with a thousand faces," whose obscure origins and infant exile ultimately yield the promise of a brilliant future. ${ }^{23}$ The Russian realization of Campbell's archetype is fractured, of course, since the promised future fails to materialize, whether because the hero is a scoundrel or because his contemporaries fail to recognize him and spoil his hopes. It is the chain of events following this fracture that produces trauma. In this reading, Russians have consistently failed to integrate the disasters that accompanied Dmitry's defeat (or their own) and, as a result, have been regularly impelled to reenact them. As appealing as such a reading is, however, it slightly misses the mark. Most studies of trauma literature have addressed twentieth- and twenty-first-century plays and novels that were written in close proximity to

20 Michelle Balaev argues for a maximally flexible framework for understanding trauma that "emphasizes the multiplicity of responses to an extreme experience and the importance of cultural factors in determining the significance of the event (The Nature of Trauma in American Fiction [Evanston, IL: Northwestern University Press, 2012], xi).

21 Alan Gibbs identifies both narratives about US aggression in Vietnam and those about the Holocaust as examples of perpetrator and victim trauma literature, respectively (Contemporary American Trauma Narratives [Edinburgh: Edinburgh University Press, 2014], 18-19).

22 Viljoen and van der Merwe's research focuses on South African apartheid and the literature it has generated.

23 Joseph Campbell, The Hero with a Thousand Faces (New York: Pantheon, 1949), 321-26. 
their authors' experiences of the represented trauma. ${ }^{24}$ The immediacy of the literary response ameliorates any potential ambiguity regarding the identity of the distress being reenacted. By contrast, although a number of Dmitry prefictions were written immediately after his reign, fully realized fiction followed at a considerable temporal remove. It is highly unlikely that each and every one of these later fictions constituted a response to one and the same precipitating trauma.

Ilya Kliger and Boris Maslov follow Aleksandr Veselovskii in positing a "non-linear model of history traversed by traces of the past." 25 By this they mean that "manifestations of verbal creativity do not disappear with the stage of social development that gave them birth but, rather, become reanimated when the socio-political demand for them arises again," creating "point[s] of nonconvergence between the recursive temporality of culture on the one hand and the progressive conceptions of historical time on the other." ${ }^{26}$ Of particular relevance to the Dmitry tradition is Kliger and Maslov's notion of sociopolitical demand: individual moments in cultural history have created the conditions for the reemergence of a specific type of protagonist, who, in turn, resurrects the Time of Troubles in order to illuminate contemporary challenges. Thus, while Dmitry fictions are responses to trauma, the trauma in question can be localized to the moment of their composition as well as universalized to the moments they depict. The Time of Troubles is assimilated to late eighteenthcentury and nineteenth-century traumas by analogy: at various points in history, the harrowing elements of Dmitry's story have been read as simulacra for other current disruptions.

This raises the issue of continuities and discontinuities. In what ways do later cultural periods resemble and/or differ from earlier ones? How is the trauma of each period processed by its literary texts? What is the method of transference? While the phenomenon of recurrence is diachronic, transference is synchronic. Its mechanisms should, at least in theory, resemble those enlisted by new historicists. In Stephen Greenblatt's words, new historicism consists in

24 Laurie Vickroy goes so far as to assert that trauma narratives are a contemporary phenomenon (Reading Trauma Narratives [Charlottesville: University of Virginia Press, 2015], 3). Catherine Silverstone, by contrast, has added a longer-term diachronic perspective but focuses on performance history when reading violence in Shakespeare (Shakespeare, Trauma and Contemporary Performance [London: Routledge, 2011]).

25 Ilya Kliger and Boris Maslov, "Introducing Historical Poetics: History, Experience, Form," in Persistent Forms: Explorations in Historical Poetics, ed. Ilya Kliger and Boris Maslov (New York: Fordham University Press, 2016), 5.

26 Ibid., 5, 6. 
"develop [ing] terms to describe the ways in which material ... is transferred from one discursive sphere to another and becomes aesthetic property." ${ }^{27}$ Building on Frederic Jameson's call to study the "more tangible" historicity of how we read the past through the lens of contemporary culture, ${ }^{28}$ Greenblatt's new historicism seeks "to deepen our sense of both the invisible cohesion and the half-realized conflicts in specific cultures by broadening our view of their significant artifacts." 29 Scholars have applied new historicist insights with particular success to Elizabethan and Jacobean literature, illuminating a discrete period - the early modern — as well as a discrete genre-drama-both of which are highly germane to the Dmitry tradition. ${ }^{30}$

Although many new historicists have readily acknowledged the utility, and even the necessity, of diachrony as well as synchrony, they have unfortunately tended to focus their practical readings of texts almost exclusively on synchrony. ${ }^{31}$ Such an approach is too one-sided. To adopt a rigorously new historicist reading of Dmitry texts would be to leave the critical dimension of recurrence unexplained. What is needed is a methodology that balances transference with recurrence and synchrony with diachrony, in practice as well as in theory. The so-called new formalism is even more extreme in this regard. For example, one staunch proponent, Evan Horowitz, has condemned the insights offered by new historicism out of hand, arguing that historicizing literature entails an unreasonable risk: in his view, certain aspects of historical experience cannot be integrated into literature at all, while those that can "must pay a hefty toll." 32 Marjorie Levinson, who participates in new formalism as a "movement"

27 Stephen Greenblatt, “Towards a Poetics of Culture," in The New Historicism, ed. H. Aram Veeser (New York: Routledge, 1989), 11.

28 Frederic Jameson, The Political Unconscious: Narrative as a Socially Symbolic Act (Ithaca, NY: Cornell University Press, 1981), 9.

29 Catherine Gallagher and Stephen Greenblatt, Practicing New Historicism (Chicago: University of Chicago Press, 2000), 13-14.

30 Even scholars working on the periphery of literary studies have adopted some of its premises. The philosopher Stanley Cavell, for instance, has suggested that "Shakespeare could not be who he is ... unless his writing is engaging the depth of the philosophical preoccupations of his culture" (Disowning Knowledge in Six Plays of Shakespeare [Cambridge: Cambridge University Press, 2003], 2).

31 In Louis A. Montrose's words, Greenblatt "reorients the axis of inter-textuality, substituting for the diachronic text of an autonomous literary history the synchronic text of a cultural system" ("Professing the Renaissance: The Poetics and Politics of Culture," in The New Historicism, ed. H. Aram Veeser [New York: Routledge, 1989], 17).

32 Evan Horowitz, "Narrative Accidents and Literary Miracles," Philosophy and Literature 35 (2011): 66. Peter Sinnot fires back, criticizing Horowitz for "a gross misunderstanding of the nature of historical events as well as a misunderstanding of historically oriented criticism" 
rather than a strict methodology or theory, attacks new historicism for its denigration of form, implying that critics are faced with the stark choice of privileging either form or history. ${ }^{33}$ Renate Lachmann, revisiting the insights of the Russian formalists, similarly overstates her case, suggesting that the relationship between an old and a new text is necessarily parodic. ${ }^{34}$

There is, however, a more nuanced position. Dominick LaCapra has called for the development of theoretical approaches "that are historically informed and critically alert to the interpretations of specific artifacts without being either narrowly historicist ... or formalist." ${ }^{35}$ In a similar spirit, Stephen Cohen has drawn attention to literary theory's repeated oscillations between the poles of form and history and urged critics to overcome these extremes by synthesizing formalism and historicism into what he has christened "historical formalism." ${ }^{36}$ Exploring "the complexity of the mutual implication of literary form and history," ${ }^{\prime 3}$ historical formalism is less a method than a critical commitment to offer equal consideration to "literature's formal individuation and its historical situation in order to illuminate at once text, form, and history." 38 Cohen recognizes literary texts as the products of historical circumstances, while at the same time granting them ideological significance as specifically literary representations. ${ }^{39}$ Thus, historical formalism squares the critical circle by detecting "the stealthy motions of history in the forms of a cultural artefact, rather than just in its raw content." ${ }^{40}$ In analyzing the Dmitry tradition, I consider fiction's forms as well as its content (trauma, understood synchronically as well as diachronically).

Literary form, like literary trauma, can be studied either dynamicallyin its historical evolution_or statically_as frozen at a given point in that

("Morality, Historical Narrative, and Problems in the New Formalism," Philosophy and Literature 37 [2013]: 257).

33 Marjorie Levinson, "What Is New Formalism?" PMLA 122 (2007): 558-59.

34 Renate Lachmann, Memory and Literature: Intertextuality in Russian Modernism, trans. Roy Sellars and Anthony Wall (Minneapolis: University of Minnesota Press, 1997), 36.

35 Dominick LaCapra, History, Politics, and the Novel (Ithaca, NY: Cornell University Press, 1987), 7.

36 Stephen Cohen, "Introduction," in Shakespeare and Historical Formalism, ed. Stephen Cohen (Burlington, VT: Ashgate, 2007), 1-3.

37 Robert Hampson, Conrad's Secrets (Basingstoke: Palgrave Macmillan, 2012), 25.

38 Cohen, Shakespeare and Historical Formalism, 3.

39 Stephen Cohen, "Between Form and Culture: New Historicism and the Promise of a Historical Formalism," in Renaissance Literature and Its Formal Engagements, ed. Mark David Rasmussen (New York: Palgrave, 2002), 32.

40 Terry Eagleton, Figures of Dissent: Critical Essays on Fish, Spivak, Žižek and Others (London: Verso, 2003), 4. 
evolution. At various stages in the development of the modern fictional Dmitry tradition, texts have been realized in one of two different genres: either as plays or as novels. Along with documenting and explaining the processes of recurrence and transference at work in the content of each cluster of Dmitry texts, I also focus on them with regards to genre. How did genre choice change over time? Was it largely predetermined - that is, was an author responding directly to a previous text written in the same genre-or did he write during a period that favored one genre over another ${ }^{41}$ Did each author's choice articulate in some discernible way with his approach to his raw material? To contemporary issues? If so, how?

In this introductory chapter, it suffices to offer a few generalizations concerning dramatic and novelistic discourse. Both genres share in the meanings circulating at the time of their composition, of course, ${ }^{42}$ and both operate with an authorially imagined and constructed plot: unlike history, plays and novels "articulate a meaning for human suffering that does not emerge from the random mess of events." 43 But plays provide a less mediated articulation: in Thornton Wilder's lucid formulation, "A play is what takes place. A novel is what one person tells us took place." ${ }^{4}$ Plays occur in the present tense, whereas novels occur in the past; additionally, plays come to their audiences directly through the words of their characters, without an intervening narrator. Thus, drama can be viewed as a "reduced form" because it does not utilize the full range of levels and modes of mediation. ${ }^{45}$ Conversely, drama can also be viewed as a fuller form because it speaks not only through language but also through gestures and facial expressions as well as through objects located onstage: "In performance, characters ... utilize duration and presence to create a complex perceptual web which ... allows the spectator a freedom of response quite different from and more inclusive than that offered by the printed text." 46

41 Throughout Writing the Time of Troubles, I will refer to Dmitry authors as "he." To the best of my knowledge, no female writers have tackled Dmitry fiction.

42 Catherine Belsey, The Subject of Tragedy: Identity and Difference in Renaissance Drama (London: Methuen, 1985), 5.

43 Rebecca Bushnell, Tragedy: A Short Introduction (Malden, MA: Blackwell, 2008), 53.

44 Thornton Wilder, The Collected Plays of Thornton Wilder, ed. A. Tappan Wilder (New York: Theatre Communications Group, 1998), 2:271.

45 Peter Hühn and Roy Summer, "Narration in Poetry and Drama," in The Living Handbook of Poetry and Drama, http://wikis.sub.uni-hamburg.de/lhn/index/php/Narration_in_ Poetry_and_Drama.

46 Marvin Carlson, "Psychic Polyphony," in Modern Theories of Drama, ed. George W. Brandt (Oxford: Clarendon, 1998), 292. As Anthony Swift has noted, "the theater's potent mix 
Moreover, drama's relative lack of mediation leads to a greater degree of dialogicity: drama allows its characters both to speak and to listen, to consider and to reconsider, much more actively and nimbly than prose does. ${ }^{47}$ Prose, by contrast offers its narrator much greater scope for evaluating the wisdom and/or morality of characters' actions.

In part, Dmitry authors chose to write either novels or plays based on extrinsic factors: on the one hand, they took their fellow authors' as well as their audiences' expectations into consideration; on the other, they faced a variety of restrictions, particularly under Nicholas I-in 1837 the emperor ruled that only pre-Romanov tsars could be shown on stage. ${ }^{48}$ However, Dmitry authors also were alive to factors inherent to the genres they chose. In The Content of the Form: Narrative Discourse and Historical Representation, Hayden White elaborates a theory of historiographical narration that he partially extends to fiction. In comparing annals, chronicles, and "history proper," he asserts that only history proper treats events within a structure and order of meaning that transcends mere sequentiality. Only history proper, in other words, achieves true narrativity ${ }^{49}$ Following Hegel, White suggests that narrative representation always entails a conflict between desire and law, from which he concludes that "narrative in general, from the folktale to the novel, from the annals to the fully realized 'history,' has to do with the topics of law, legality, legitimacy, or, more generally, authority." ${ }^{50}$ Unlike "proper" historians, annalists lack "the capacity to substitutemeaningsforone anotherin chains ofsemanticmetonymies that would transform [their] list of events into a discourse about the events considered as a totality evolving in time." ${ }^{51}$ Chronicles fall midway between history proper and annals: they approach but do not fully achieve narrativity because they lack closure; they break off in medias res, in the chronicler's own

of visual impressions and spoken words was believed to have a greater impact than mere printed words" ("Russia," in The Frightful Stage: Political Censorship of the Theater in Nineteenth-Century Europe, ed. Robert Justin Goldstein [New York: Berghahn, 2009]), 131.

47 Hühn and Summer point out that drama provides at least a limited degree of mediation through "selection, segmentation, combination, and focus of the scenes" ("Narration in Poetry and Drama"). On drama versus prose, see Keir Elam, The Semiotics of Theatre and Drama (London: Routledge, 2002), 125.

48 Occasional exceptions were made for historical dramas with strong patriotic content (Swift, "Russia," 138).

49 Hayden V. White, The Content of the Form: Narrative Discourse and Historical Representation (Baltimore: Johns Hopkins University Press, 1987), 5.

50 Ibid., 10-11.

51 Ibid., 16. 
present, leaving their content unresolved. In White's view, however, annals and chronicles are not failed, inferior anticipations of historical discourse but, rather, alternatives to it. ${ }^{52}$

Building on White's insights into narration, law, and legitimacy, I would suggest that historical drama occupies a position vis-à-vis the novel somewhat analogous to the one that chronicles enjoy vis-à-vis history proper, which is to say that drama offers an alternative mode of representing conflict. ${ }^{53}$ As has already been noted, in the absence of an authoritative narrator, drama can be less objective in drawing overarching conclusions than the novel. Occurring in the present, drama must rely on its audience's experience to supply a distanced perspective. Its confrontation with systems of law and legitimacy is therefore inherently dialogic. Although drama, unlike the chronicle, ultimately achieves a type of closure, throughout its performance it offers the opportunity for powerful voices, which exist within a perpetual present tense, to challenge one another.

In Writing the Time of Troubles I move chronologically through the text clusters identified above. I read the earliest play or novel in each cluster, on the one hand, as a kind of ur-text with which the writers of subsequent texts enter into dialogue and, on the other, as a discursive artifact participating in a multigeneric conversation about current Russian affairs. I also read diachronically, placing each cluster into conversation with previous Dmitry fiction. Chapter 1 is prefatory, offering a reading of one short, protofictive seventeenth-century tale, The Story of Grishka Otrepev, as well as of the earliest extant saints' life written about the child Dmitry. It touches on what I refer to as the "raw material" of the Dmitry tradition and shows that late medieval Russians had not yet teased out discrete fictional and nonfictional functions from within the generalized discourse of many of their narrative genres. Chapter 2 addresses the long eighteenth century. Chapter 3 covers the particularly rich cluster of

52 Ibid., 5-6.

53 Although many critics have argued that drama does not constitute a subcategory of "narrative," others have contended the opposite. Explicit arguments in favor of considering drama under the aegis of narrative have been made, for example, by Brian Richardson, "Drama and Narrative," in The Cambridge Companion to Narrative, ed. David Herman (Cambridge: Cambridge University Press, 2007), 142-55, as well as by Manfred Jahn, "Narrative Voice and Agency in Drama: Aspects of a Narratology of Drama," New Literary History 32 (2001): 659-79. Jahn believes that "plays have a narrative world (a 'diegesis'), which is not distinct in principle from any other narrative world" (674). Hanna Scolnicov implies much the same in her introduction to Reading Plays: Interpretation and Reception, ed. Hanna Scolnicov and Peter Holland (Cambridge: Cambridge University Press, 1991), 1-7. 
Dmitry texts produced in the 1820s and 1830s, while Chapter 4 deals with two plays written in response to the Era of Great Reforms. Chapter 5 looks at imperial Russia’s final Dmitry cluster. Mindful that not all readers will be versed in Russian history and politics, I contextualize cultural transference at the beginning of each chapter through a brief summary of the most apposite political issues of the day. Additionally, I lay the groundwork for the chapter's discussion of recurrence by offering a few initial words about pertinent developments in the era's historiography. 
